\title{
Pesticide risk assessment and management in a globally changing world-report from a European interdisciplinary workshop
}

\author{
Marc Babut • Gertie H. Arts • Anna Barra Caracciolo • Nadia Carluer • \\ Nicolas Domange • Nikolai Friberg • Véronique Gouy • Merete Grung • \\ Laurent Lagadic • Fabrice Martin-Laurent • Nicolas Mazzella • \\ Stéphane Pesce • Benoit Real • Stefan Reichenberger • Erwin W. M. Roex • \\ Kees Romijn • Manfred Röttele • Marianne Stenrød • Julien Tournebize • \\ Françoise Vernier • Eric Vindimian
}

Received: 4 July 2013 / Accepted: 10 July 2013 /Published online: 23 August 2013

(C) The Author(s) 2013. This article is published with open access at Springerlink.com

\section{Introduction}

Global change, in particular climate change, will affect agriculture worldwide in many ways: increased drought or flooding amplitude and frequency, variable temperature increases, loss of natural depuration of waters, soil erosion, loss of soil carbon content, invasion by alien species, increased pest events, changes in plant phenology, increased sensitivity

Responsible editor: Philippe Garrigues

M. Babut $(\bowtie) \cdot$ N. Carluer $\cdot$ V. Gouy $\cdot$ S. Pesce

Irstea, UR MALY, 5 rue de la Doua, CS70077,

69626 Villeurbanne, France

e-mail: marc.babut@irstea.fr

G. H. Arts

Alterra, Wageningen University and Research Centre, P.O. Box 47, 6700 AA Wageningen, The Netherlands

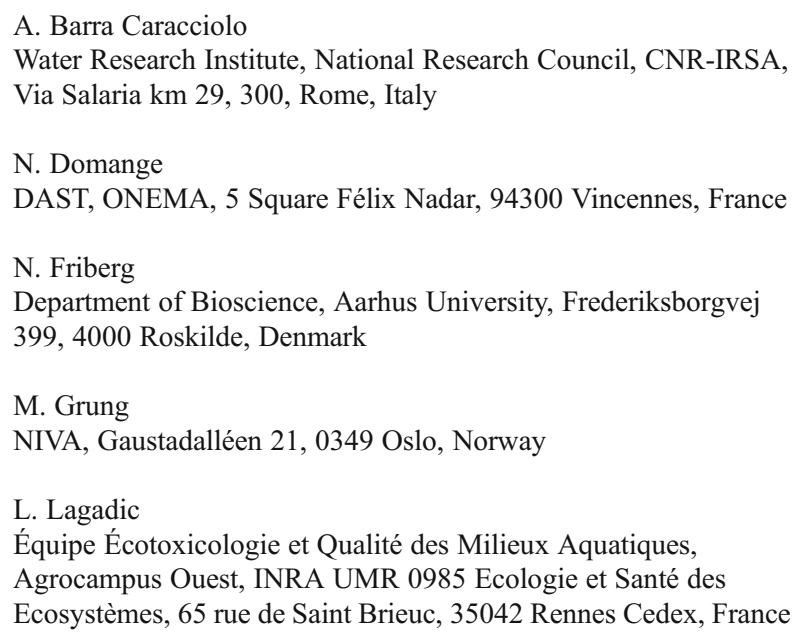

of crops to stress and diseases etc. (Fisher et al. 2005; Howden et al. 2007). These anticipated or even already occurring stresses raise concerns about the sustainability of production and the ability of agriculture to feed human populations. All these changes could lead to an increased use of pesticides (Kattwinkel et al. 2011). Moreover, demographic pressure continues to rise, in particular in tropical and sub-tropical regions, where greater threats to agriculture and food

F. Martin-Laurent

INRA UMR 1347 Agroécologie, 17 rue Sully, BP 86510,

21065 Dijon, France

N. Mazzella

Irstea, UR REBX, 50 avenue de Verdun - Gazinet,

33612 Cestas, France

B. Real

ARVALIS - Institut du Végétal, CS 30200, Estrées Mons, 80208 Peronne, France

S. Reichenberger

Footways S.A.S., 10 avenue Buffon,

45071 Orléans Cedex 2, France

E. W. M. Roex

Deltares, P.O. Box 85467, 3508 AL Utrecht, The Netherlands

K. Romijn

Bayer SAS Environmental Sciences, 16 rue Jean Marie Leclair, 69009 Lyon, France

M. Röttele

Better Decisions, Haverlandhöhe 21a, 48249 Dülmen, Germany 
sustainability are anticipated by the Intergovernmental Panel on Climate Change (IPCC) (Easterling et al. 2007). These trends will certainly lead to mounting conflicts involving water uses (irrigation versus drinking water production or freshwater ecosystem maintenance, sanitation etc.) and food production. This appeals to an "ecologically intensive agriculture" (Griffon 2006), i.e. a sustainable agriculture providing ecosystem services more efficiently than today and causing fewer adverse impacts on the environment and water resources.

With EU Directive 2009/128/EC (EC 2009a) enforcement, requesting Member States to adopt action plans aiming to reduce risks and impacts related to pesticide uses, there will be a focus in the public and political debates in Europe on achieving a more sustainable use of pesticides. This should consequently lead to a reduction of the risks or impacts of pesticides on the environment. In Europe, there is currently a strong focus on source (including dose) reduction. This approach may nevertheless be too restrictive if the goal is to reduce the agriculture footprint while maintaining or increasing yield. Depending on the chemical properties of pesticides as well as environmental factors, decreasing the amounts of pesticides applied to crops will not automatically produce a decrease in the risk to non-target species or water supply.

How could society meet the challenge of the forthcoming climate change? What adaptations should be envisaged for agriculture/pesticide risk management (RM)? These changes will probably have a profound effect on agricultural systems (crop selection, farming practices etc.) and to a lesser extent influence the fate and effects of chemicals (Schiedek et al. 2007). These questions have been addressed by two European research networks, namely Euraqua (the European Network of Freshwater Research Organisations, http://www.euraqua.org/) and PEER (Partnership for European Environmental Research, http://www.peer.eu/), which organised a workshop aiming to identify research needs and strategies induced by these questions in October 2011 in Montpellier, France.

The workshop's specific goals were to (1) discuss the pesticide risk assessment (RA) approach, its limitations (e.g.

\section{Stenrød}

Norwegian Institute for Agricultural and Environmental Research (Bioforsk), Høgskoleveien 7, 1432 Aas, Norway

J. Tournebize

Irstea, UR HBAN, 1 rue Pierre-Gilles de Gennes, CS 10030, 92761 Antony, France

F. Vernier

Irstea, UR ADBX, 50 avenue de Verdun - Gazinet,

33612 Cestas, France

E. Vindimian

Irstea, SGMO, 361 rue Jean-François Breton,

34196 Montpellier, France spatial scale and multi-stress situations), the connections between different policies (pesticide regulation and Water Framework Directive), the use of models, (2) review integrated practices and innovative technologies which could or are intended to reduce pesticides' environmental impacts and (3) contribute to the future research and development agenda. This review summarises the workshop discussions.

\section{Climate change}

Implications for ecosystems

The Earth's average surface temperature is predicted to rise at a faster rate than previously experienced by human civilisation (Parmesan \& Yohe 2003; Thomas et al. 2004). Furthermore, the global water cycle is altered by climate change, which in turn affects local aquatic ecosystems (Vörösmarty et al. 2010). Although there are major uncertainties in the estimates of climate change, future shifts in hydrological regimes and increased temperatures are likely to place considerable environmental stress on many natural systems in the near future. Profound changes have already been reported from many vulnerable ecosystems in recent decades (e.g. (Schofield et al. 2010)) and by inference from experimental studies, either natural (e.g. (Woodward et al. 2010)) or in man-made set-ups (e.g. (Ledger et al. 2013)). The effects of climate change will permeate all levels of biological organisation, from species to ecosystem-level impacts. Several studies have demonstrated enhanced toxicity for organisms not adapted to increased temperatures (Ferrando et al. 1987; Lydy et al. 1999; Prato et al. 2008). Subtle changes in environmental conditions or key species abundance can cause shifts in species population ranges (e.g. (Levinsky et al. 2007)) as well as impacts on ecological networks (Meerhoff et al. 2007; Woodward et al. 2010; Ledger et al. 2013). Elevated temperatures are likely to increase overall metabolism and nutrient uptake of freshwater ecosystems, making them susceptible to eutrophication (Demars et al. 2011). Furthermore, cold stenotherms will disappear, and this could alter betadiversity (Woodward et al. 2010; Friberg et al. 2013). Experiments have shown that the entire food web structure can collapse with the loss of apex predators under drought conditions (e.g. (Ledger et al. 2013)).

However, uncertainties surrounding climate change impacts remain high, as stressed by a recent SETAC workshop (Stahl et al. 2013): (1) human-mediated mitigation of, and adaptation to, climate change impacts may have as much influence on the fate and distribution of chemicals as climate change, and modelled predictions should be interpreted cautiously. (2) Climate change and chemical toxicity affect each other mutually. (3) The effects of climate change may be slow, variable and difficult to detect, though some highly vulnerable 
populations and communities may exhibit responses sooner and more dramatically than others. (4) Future approaches to human and ecological RAs will need to incorporate multiple stressors and cumulative risks considering the wide spectrum of potential impacts stemming from climate change. (5) Baseline/reference conditions for estimating resource injury and restoration/rehabilitation will continually shift due to climate change and represent significant challenges to practitioners.

The consequences of climate change are a challenge for risk assessors and risk managers, as they will create different ecological communities from the current ones (no-analogue communities), making it difficult to define a priori deviations from reference conditions (Landis et al. 2013). Type III errors, i.e. when a correct analysis is conducted on erroneous premises, are therefore likely to occur. The above-mentioned SETAC workshop pointed out four fundamental considerations that could help risk assessors to cope with climate change (Landis et al. 2013): (1) consider interactions among stressors, including those related to climate change - new temperature and precipitation regimes, modified hydrological processes; (2) adopt more appropriate regulatory endpoints than the current hazard quotient or its variant; (3) develop an understanding of stochasticity, tipping points and multi-stressor interactions; and (4) given that biological responses to environmental stressors will likely be nonlinear, specially under climate change, the previous reliance on null hypothesis models needs to be discarded. Furthermore, these authors develop different principles for guiding future RAs, in particular to consider the importance of climate changerelated factors in the RA process and subsequent management decisions because climate change will not always be an important factor in future RAs, to express assessment endpoints as ecosystem services, to consider positive as well as adverse responses of ecosystem services (endpoints), to develop multiple-stressor approaches and to implement conceptual cause-effect diagrams that consider relevant management decisions as well as appropriate spatial and temporal scales to allow consideration of both direct and indirect effects of climate change. They also suggest identifying the major drivers of uncertainty and continuing the process as management activities are implemented, and finally plan for adaptive management to account for changing environmental conditions and consequent changes to ecosystem services.

Implications for agriculture and potential consequences for pesticide emissions

The possible direct effects of climate change on the diffuse emissions of pesticides are difficult to estimate because of the uncertainties associated with the forecast of climate change itself and the fact that the anticipated effects can be contradictory (Jacob et al. 2007). Indeed, changes in the seasonal variation of rainfall, its intensity and frequency, can lead to a decrease in the spring and winter rainy event occurrence, but also to an increase in their intensity. The majority of predictions agree that, in addition to an increase in temperature, spring will become wetter in North-Western Europe, whereas the frequency of extreme precipitation events will increase in summer (e.g. (Lehner et al. 2006)). This change in climate will increase surface run-off events in periods when agricultural production is high and could lead to an increased risk of pesticide exposure of the aquatic biota. A temperature increase can imply a subsequent rise in the biodegradation rates of chemicals, in both aquatic and terrestrial ecosystems. In freshwater ecosystems, increasing temperature will reduce their ability to cope with increased nutrient levels (Friberg et al. 2009; Jeppesen et al. 2010). In soil ecosystems, biodegradation is dependent on sufficient soil moisture (Bouseba et al. 2009). Climate change along with intensive and unsustainable agricultural practices contribute to soil degradation and loss of biodiversity (Jeffery et al. 2010; Turbé et al. 2010). The ability of soil and water to recover from pesticide contamination is primarily dependent on the presence of an abundant and diverse microbial community with the ability to remove contaminants (Barra Caracciolo et al. 2013). The sensitivity or resilience of ecosystems to chemicals might also be affected. At the European scale, climate change impacts are likely to lead to contrasted outcomes. Future projected trends in European agriculture include a northward shift of crop suitability zones and increasing crop productivity in Northern Europe, but declining productivity and crop viability in southern areas (Olesen \& Bindi 2002; Falloon \& Betts 2010). Climate change impacts differ per crop and per $\mathrm{CO}_{2}$ emission scenario; whereas crops planted in autumn and winter may benefit from the increasing $\mathrm{CO}_{2}$ concentrations, those planted in spring may benefit less because of the increasing temperature and reduced rainfall (Supit et al. 2012). Climate change will alter the environmental conditions for crop growth and require adjustments in management practices at the field scale such as irrigation and fertilisation. These factors can be modelled using crop growth models, but the currently available models are not able to simulate biotic components of cropping systems, especially pests, plant diseases, weeds and beneficial organisms (Bergez et al. 2010; Lehmann et al. 2013). Finally, some (e.g. (Bloomfield et al. 2006; Kattwinkel et al. 2011) argue that, over the long term, most of the modifications induced to agricultural systems by climate change will be indirect, i.e. not governed by direct impacts of changes in water temperature on organisms but by indirect impacts related to changes in farming practices, and therefore quite difficult to anticipate through adaptation measures.

In the meantime, it will become even more critical to address both quantitative and qualitative aspects in water 
management, in order to reconcile the requirements for drinking water, irrigation and ecosystem integrity.

\section{Pesticide risk assessment and management: the need for a more holistic approach}

The ecological RA and management of pesticide use in Europe and the protection goals of related ecosystems have recently been debated by a stakeholders' panel appointed by the European Food Safety Authority (EFSA). Specific protection goals need to be defined based on a combination of (1) the ecological entity to be protected (e.g. individual, population and functional group), (2) the relevant attribute of that entity (e.g. behaviour, abundance and function), (3) the magnitude of the effect for the attribute (e.g. small, medium and large), (4) the temporal scale (e.g. days, weeks and months) and (5) the spatial scale of the effect (e.g. field, edge of field and landscape; (Nienstedt et al. 2012)).

Conceptually, pesticide RA and management activities can be represented as a cycle alternating RA, RM and monitoring in a continuous improvement process (Fig. 1). The EuraquaPEER workshop attendees discussed the approaches available or desirable for exposure or effect assessments, as well as RM and monitoring. They also acknowledged that this cycle tends to be virtual, in that the steps are often disconnected.

Within the European Union, current pesticide RAs are performed on one hand under the 1107/2009 Regulation (EC 2009b) dealing with issuing plant protection products to the market, and the "sustainable use" directive (EC 2009a), which together replace the former 91/414/EEC directive, and on the other hand the Water Framework Directive (WFD, (EC 2000)). Conceptually very different, these texts might lead to contradictions. The WFD addresses

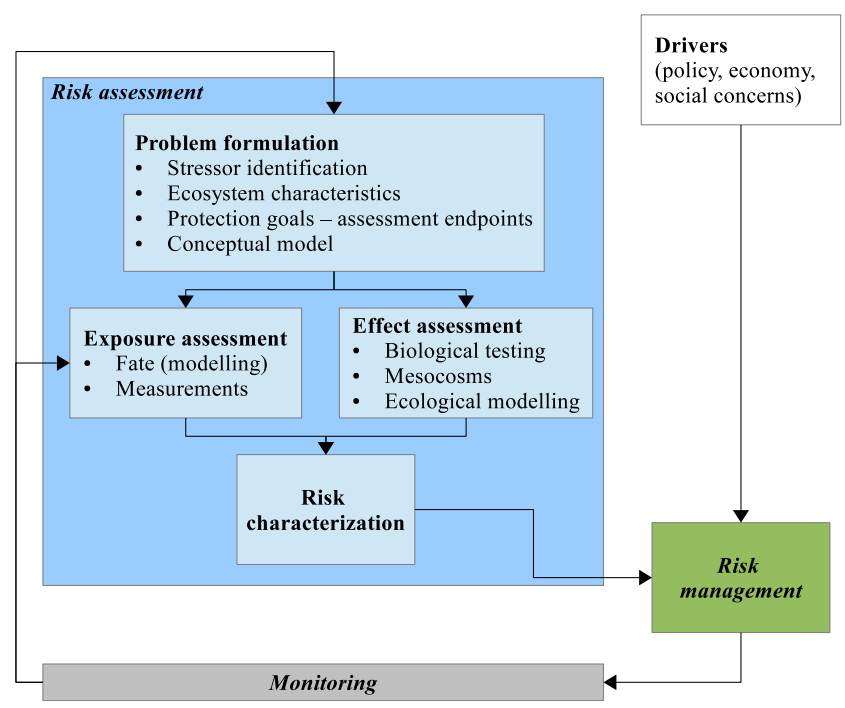

Fig. 1 The risk management cycle (adapted from USEPA 1998) both short- and long-term risks, expressed as Maximum Acceptable Concentrations (MACs) Environmental Quality Standards (EQSs) and Annual Average EQSs (AA-EQSs), respectively, and does not explicitly envisage a tiered approach. Pesticide regulation also distinguishes short- and long-term risks but follows a tiered approach (Brock et al. 2011). None of these assessment procedures account for multiple stressors (e.g. nutrients and pesticides), nor do they address the spatial-temporal variability of exposure conditions. This appeals for coupling fate and exposure modelling with toxicity testing, either standard tests or higher-tier testing and mesocosm studies. The current risk characterisation approach, based either on hazard quotients or species sensitivity distribution, is deemed to target the structure of communities and abundance of (sensitive) species. As such, it does not consider whether or not, and if yes at which rate, populations will recover (Kefford et al. 2012).

Another conclusion of the workshop pointed to the loose or missing link(s) between the different stages of the RM cycle. A management measure, such as a nominal reduction of applied doses, may be decided without any prior RA. Moreover, management measure efficiency is often not monitored. Ex ante assessment of management measure efficiency would assume being able to model their consequences at the right scale, i.e. to quantify the resulting evolution of the water-quality indicators. However, while relevant models simulating pesticides' fate at the field scale are available (Adriaanse et al. 1996; Tiktak et al. 2000; Vanclooster et al. 2000; Carsel et al. 2003; Larsbo et al. 2005), there is still a need to develop tools at the catchment scale. Indeed, fully or semi-distributed hydrological models exist at the catchment scale, such as HSPF (Donigian et al. 1983), SWRRB (Arnold et al. 1991) or SWAT (Neitsch et al. 2009), but they poorly account for the influence of landscape characteristics. For example, the semi-distributed hydrologic response unit (HRU) approach used in SWAT does not properly assess the influence of man-made structures, such as vegetative strips, hedges, ditches or constructed wetlands, subsurface drainage systems and even the road network, on pesticide fate and transport to the surface water network, whereas the role of these features has been demonstrated in several studies (e.g. (Doppler et al. 2012)). The influence of such features on water flows at a small catchment scale was included in distributed models such as ANTHROPOG (Carluer \& De Marsily 2004) and MHYDAS (Moussa et al. 2007). Nevertheless, these examples are primarily research models, which are difficult to use for management purposes. Management-oriented approaches combining pesticide fate models and indicators might be more efficient (GascuelOdoux et al. 2009); similarly, (Dubus et al. 2009) combined the output of the field-scale runoff and erosion model PRZM with a grid-based routing to the surface water network. Furthermore, in a catchment, not all areas contribute equally 
to pesticide inputs into surface waters, and so-called critical source areas (CSAs) provide the major part of the contaminant load to surface water (Leu et al. 2004; Freitas et al. 2008; Frey et al. 2009; Doppler et al. 2012). It is important for RA and management to identify and properly model the CSA, but this requires the availability of high-resolution spatial input data (notably a digital landscape model including man-made features) and a fully distributed hydrological model.

Another difficulty is to define and choose the indicator (or set of indicators) on which to rely to define whether or not management measures are efficient regarding water quality: such an indicator should give information on both extreme and average contamination as well as cover several species and, ideally, functional changes in the ecosystem. One can easily understand that a single indicator cannot answer all these questions. The overall consequences of management measures, such as reducing soil erosion and nutrient losses may be overlooked to a large extent. There is a need to establish a better knowledge base to enable proper weighting of contrasting environmental concerns in relation to the soil and water ecosystem services in the desired indicator or set of indicators.

Information systems in support of a modern management of agro-ecosystems

A successful implementation of RM measures can only be achieved by a better understanding of the interactions between land use (pesticide pressure) and the environment. One way of doing this is to calculate agro-environmental indicators (AEI), which account for both pressure and vulnerability of surrounding ecosystems. However, this approach requires an effective information system that can process both the characteristics of the river basin and the agricultural activities at different scales: the small agricultural catchment scale for action by farmers, monitoring of protected areas and a larger watershed scale for public decision making. Such environmental information systems would benefit from the spatial data warehouse technology. These information systems can qualify agricultural activities (Schneider 2008; Pinet et al. 2010) along with river basin characteristics and can calculate various integrated indicators, or conversely disentangled ones, at different scales.

\section{Risk assessment}

Effect assessment: is the current approach sufficient?

In regulatory RAs, many pesticides do not meet the first-tier criteria and are subject to higher-tier assessments. For these higher-tier-effect assessments, laboratory and outdoor microcosms or mesocosms are good compromises between the "real" field tests and standard laboratory tests (Brock et al. 2006). They can be conducted under different natural conditions, e.g. temperature, light or humidity, in order to evaluate the fate and effects of pesticides in different environmental exposure scenarios. Furthermore, they make it possible to study multiple stressors, such as pesticide mixtures, copresence of nutrients and organic contaminants, and the combination of climatic factors with contaminants (Arts et al. 2006; Barra Caracciolo et al. 2013). They can also be designed so as to encompass indirect effects on the food web. The microcosm/mesocosm approach using realistic exposure conditions could therefore be used for assessing the effects of multiple pesticide applications in realistic worst-case scenarios at higher ecological levels (Arts et al. 2006).

Ecological modelling is currently very much in progress (Grimm et al. 2009; Galic et al. 2010; Hommen et al. 2010; Zhang et al. 2013). Results gained from experiments in the context of higher-tier assessments have to be extrapolated to the field under various scenarios; these extrapolations need to account for multiple pesticide applications and climate change. However, it is a big challenge to have these ecological models fit for the purposes of use in chemical RA while being relevant for ecosystems. (Moe et al. 2013) and (Galic et al. 2010) recommend developing this type of ecological modelling on the basis of species traits, representing life-history traits, population vulnerability, sensitivity to toxicants and sensitivity to climate change, as a promising approach for predicting the combined impacts of climate change and toxicants on populations and communities.

The effects of climate change on soil communities need to be more adequately addressed

Under the European Pesticide Regulation, lower-effect assessment tiers are based on rather simple means and a rather conservative interpretation, while higher tiers are more ecologically relevant, as they account for pesticide fate and ecological interactions, but are much more complex and less reproducible (Brock et al. 2006).

Decision trees and higher-tier ecological RAs are well developed for aquatic ecosystems (Brock et al. 2006; Brock et al. 2011) but not for terrestrial ecosystems. Currently, the ecotoxicology effects assessment required for the approval of pesticides only includes ecotoxicology studies on single target species of soil fauna and only crude measures of soil microbial activity. Since many of the ecosystem services provided by soils are related to the microbial community's diversity and functioning (Turbé et al. 2010), including the maintenance of soil and water quality (DeLong \& Pace 2001; Barra Caracciolo et al. 2010a; Barra Caracciolo et al. 2010b; Mocali \& Benedetti 2010), there is a need to compile information on species distribution and composition of other soil functional groups (e.g. soil microbial communities, meso- and 
macro-fauna communities) currently not covered in the standard RA procedures (EFSA 2010). Moreover, microbial communities are also likely to be early indicators of increased temperature effects in the climate change context (e.g. (Perkins et al. 2012)).

Technical advances call for the implementation of the more specific ecotoxic-genomic methods in the effects assessment of pesticides and other environmental stressors (van Straalen \& Feder 2012).

One may argue that the only realistic approach to obtain aquatic ecotoxicological data consists of conducting in situ studies. However, in the field, distinguishing between pollutant effects and those related to other physical, chemical or biological environmental variables remains very challenging, especially in light of climate change (Stahl et al. 2013). Pollution-induced community tolerance (PICT) is probably one of the best-adapted approaches to achieve this goal because tolerance to one toxicant is less sensitive to natural variations at sampling sites than other community characteristics (Schmitt-Jansen et al. 2008; Pesce et al. 2009). To improve the PICT methodology, special attention should be paid to co-tolerance patterns and to developing new shortterm tests designed to evaluate tolerance capacities, especially with a view to broadening the range of toxicants monitored (Blanck 2002; Tlili \& Montuelle 2011).

Even though pesticides frequently occur in mixtures (e.g. (Rabiet et al. 2010)), data on the effects of pesticide mixtures is scarce, especially when considering community-level effects (Van den Brink et al. 2009; Pesce et al. 2012). However, there is still debate over the best way to address this issue (Knauert et al. 2008; Knauert et al. 2009), and it can be argued that the assessment of mixture effects is in its infancy (Belden et al. 2007). Both WFD and pesticide regulations consider single substance risks separately. However, monitoring results show that in practice, aquatic ecosystems are exposed to a cocktail of pesticides at the same time (e.g. (Beketov et al. 2009; Rasmussen et al. 2013). These concentrations are quite often relatively low and usually do not exceed the individual EQS or probable no-effect concentrations (PNECs). However, the combined effect of these substances is not accounted for. To assess the risks of chemicals, advanced modelling predictive methods such as the msPAF (multi-species potentially affected fraction) method (Van De Meent \& Huijbregts 2005), models such as the Metapopulation model for assessing spatial and temporal effects of pesticides (MASTEP; Van Den Brink et al. 2007) or indices such as the SPEAR index (Liess \& Beketov 2011) could be used, but would not suffice for interactions with nutrients. Combining passive samplers at monitoring sites with bioassays to assess the toxicity of mixtures directly extracted from the environment has also been suggested. This approach may constitute a simple and cost-effective way to determine potential acute effects of contaminant mixtures in various aquatic environments (e.g. (Muller et al. 2007; Liscio et al. 2009; Shaw et al. 2009). Until now, this type of approach has mainly used microbial mono-specific bioassays, but (Pesce et al. 2011) showed that passive samplers can easily be combined with communitylevel toxicity testing, offering new perspectives for ecological RA, especially with a view to implementing PICT assessment for mixtures (Morin et al. 2012).

Laboratory and outdoor microcosms or mesocosms allow to study predator-prey relationships (Edwards 2002), while controlling for some sources of variability (Burrows \& Edwards 2002). They can also be applied as instruments to study the effects of climate change in a more controlled setting (Netten et al. 2010). A combination of modelling and experimental data sets enables extrapolation to higher spatial and temporal scales (Van Den Brink et al. 2007; Galic et al. 2010; Hommen et al. 2010). Laboratory microcosms, in which soil or water microbial communities are collected from natural environments, enable the evaluation of the pesticide biodegradation potential and of the effects on the soil's microbial community structure, abundance and functioning (Barra Caracciolo et al. 2010a; Barra Caracciolo et al. 2011; Udikovic-Kolic et al. 2011).

Transfer and exposure assessment: fate studies and modelling in a regulatory context

Regulatory exposure assessment, based for instance on (FOCUS 2001), involves several modelling steps, from very simple to more complex, all relying on a few generic "realistic worst case" scenarios. There are two main issues with these scenarios: representativeness and realism. First, it is almost impossible to assess the representativeness (or "protectiveness") of a few hypothetical scenarios for a whole zone or country. However, the issue of representativeness can be overcome by performing spatially probabilistic, GISbased modelling for the entire area of interest (Dubus et al. 2009), either directly for RA purposes or for deriving a set of scenarios with a known cumulative probability of being vulnerable. Several unrealistic scenario assumptions in the FOCUS surface water scenarios have been identified so far, for instance the short simulation period of 12 and 16 months for calculating pesticide concentrations in surface water, which makes it impossible to account for the inter-annual weather variability. The design of more realistic regulatory exposure scenarios seems highly desirable so as to improve the realism of the predicted exposure patterns. An example of such a scenario would address pesticide fate at the hill slope scale and consider interactions between different kinds of flow (surface runoff, erosion, lateral subsurface flow, drain flow and percolation). However, more realistic and comprehensive scenarios also require the development of more realistic and comprehensive regulatory models. For 
example, none of the four official regulatory models used in Europe for pesticide losses from fields is able to simulate all relevant pesticide transport pathways. It is worth noting here, as an important step towards more realistic exposure assessment, that regulatory vegetative filter strip scenarios are being developed (Brown 2011) for the explicit modelling of grassed buffer strips with the VFSMOD-W model (Muñoz-Carpena \& Parsons 2011).

Risk assessment: linking fate and effects

At all tiers, effect and exposure assessments have to be adequately connected (Boesten et al. 2007; Brock et al. 2010). Exposure regimes considered in higher-tier models and experiments are assumed to be realistic worst cases (FOCUS 2001). At the field level, multiple and simultaneous applications as well as time-variable and chronic exposure regimes prevail. Adequate linking of fate and effects therefore needs the translation of complicated field-exposure patterns into representative and realistic worst-case exposure scenarios to be tested in mesocosms, to be evaluated in modelling and to be compared with ecological scenarios.

Simulation models of pesticide transfers through, for example, spray drift, surface runoff and drainage provide estimates of fluxes of water and pesticides from which the amounts of compounds entering water bodies can be calculated. Further, outputs of the models can be used to simulate exposure of aquatic organisms to a series of pesticides. Such models have been used to compare exposure scenarios resulting from conventional vs. low pesticide input crop protection programs implemented on a pea/wheat/oilseed rape culture rotation in pond mesocosms (Lagadic 2011). The effects of this combination and/or succession of compounds were assessed on both structural and functional attributes of algae and invertebrate communities. The simultaneous measurement of structural and functional parameters demonstrated clear relations between community changes induced by pesticides and their functional consequences in terms of leaf-litter breakdown (Auber et al. 2011). While the overall absence of effects below ten times the PNEC suggested that these criteria are quite conservative, significant and sometimes important effects occurred when this value was exceeded.

\section{Risk management}

General management practices

The above-mentioned European regulations (EC 2000; EC 2009a; EC 2009b) have brought the use phase of pesticides into clearer focus. Unintended losses of pesticides to water originating from point sources can and should be avoided; those resulting from diffuse sources (e.g. run-off, drainage and spray drift) should also be largely reduced. An efficient RM depends first and foremost on stakeholders' risk awareness. Second, it needs a practical and understandable toolbox, making it possible to set a diagnosis at the appropriate scale and to select relevant mitigation measures.

In this perspective, a prerequisite is the operators' awareness on the correct use of pesticides, based on Best Management Practices (BMPs). In parallel, infrastructures and sprayer techniques must be steadily improved. Point-source RM is mainly concerned about the operator, optimised spray equipment and infrastructure to manage contaminated liquids on the farm, such as biobeds (Vischetti et al. 2004; Castillo et al. 2008).

Mitigation of pesticide entries into water from diffuse sources is more complex given that not all relevant factors can be controlled (e.g. weather, and more specifically the time interval between pesticide application and the first significant rainfall event; the meteorological forecast should now make it possible to prevent unduly short delays). RM should be designed and organised simultaneously at the watershed and individual plot scales. Mitigation measures concern not only individual farmers but also the community of farmers active in the same watershed. Buffer strips, for example, cannot be an effective mitigation measure if farmers do not work together in a commonly agreed way (buffers across fields). RM therefore requires practical mitigation measures but also needs to organise the social acceptance of certain measures. This often implies effective knowledge exchanges between all stakeholders.

Demonstration tools, helping to understand the risks and propose appropriate mitigation measures have been developed for either point or diffuse sources. Many of these (e.g. Aquasite or Aquavalle) are basically case studies, used for training farmers and technical advisors. Several European projects have recently been carried out for similar purposes, such as TOPPS (Train Operators to prevent Pollution from Point Sources), EOS (Environmentally Optimized Sprayers) or TOPPS-Prowadis (Protect Water from Diffuse Sources http://www.topps-life.org/). These projects allow those concerned to share views, tools and expertise throughout Europe and are expected to foster broader acceptance and support of practices adapted, eventually reducing risks. Pilot sites are also powerful demonstration tools, and may help to gather long-term observations in the meantime.

Fate models may usefully complement these demonstration tools. Nevertheless, those simulating pesticide transfer at the plot scale are most often one-dimensional. Furthermore, their design has in general focussed on one type of flow and paid less attention to the others and the interactions between these types. There is accordingly a need for catchment models which take into account both the different types of flow and the spatial variability occurring at the catchment scale (variability of soils, soil occupation and man-made structures). 
Only this type of model will be able to explain locally why water quality standards may be exceeded for some substances, and to identify which solution can remediate this situation.

Besides the data from fate studies acquired for RA, longterm data gathered in the field are useful to assess the respective influences of soil heterogeneity, climate and agricultural practices on pesticide transfer and adjust the practices so as to reduce pesticide transfers in different combinations of soil composition and climate.

\section{Indicators for pesticide RM}

An indicator is a picture (e.g. a number or a class) built with a limited set of relevant variables. Thus, a risk indicator should be a variable which provides a quantitative or qualitative estimate of risk. Risk indicators for pesticides provide simplified assessments of environmental and health risks and can thus help to promote more sustainable agriculture. For their relative simplicity, indicators may be particularly useful under conditions of limited data availability and resources (Feola et al. 2011). The most important purpose of a risk indicator is to enable a risk manager, who is not necessarily a scientist, to evaluate the risk and make informed decisions. However, in practice, there is a proliferation of indicators which are often misleading, inappropriate for the context at hand, lack scientific rigour or use misleading proxies of risk, or are insufficiently validated (Devillers et al. 2005; YliViikari et al. 2007). As a consequence, the need to develop a framework optimising and harmonising the use of pesticide risk indicators in the European Union remains current (Reus et al. 2002). The above-mentioned impacts of climate change on ecosystems are also an issue for the use of indicators, in that the initial reference conditions may no longer be encountered, or the underlying process(es) summarised by indicators may be disturbed.

\section{Ecological engineering}

Part of the amount of pesticides applied is exported from the agricultural plot to ground- and surface waters. Groundwater can then contribute to the contamination of surface water through the discharge zone, explaining why streams are still contaminated by substances that have been banned for decades (Milosevic et al. 2012). Concerning groundwater, only a reduction of pesticide pressure is possible. For surface water, however, some complementary mitigation strategies could be implemented (Reichenberger et al. 2007; Gregoire et al. 2009). The main objective is to reduce the transfer by way of buffer zones such as vegetative filter strips, artificial wetlands and forested buffers. Interception of agricultural water between the plot and the receiving water body is the key. Then ecological engineering makes it possible to value landscape components to buffer pesticide fluxes.
Pesticide dissipation in buffer zones such as buffer strips or constructed wetlands depends on complex interactions between abiotic (pesticide physicochemical properties, residence time/water flow and adsorption/desorption kinetics) and biotic factors (plant cover, soil microbial diversity, abundance and activity) gathered into retention and biodegradation processes, respectively. Taking into account that one of the factors limiting the purifying capability of buffer zones is the low pesticide concentration, ecological engineering approaches aiming at enhancing the interception of pesticide fluxes as well as the degrading capabilities of environmental microbial communities (soil and sediment) could (1) enhance the retention of pesticides in the buffer zones, so as to limit their dispersion in adjacent environmental compartments, or on the contrary, (2) favour the biodegradation of pesticides in buffer zones so as to diminish their persistence and consequently their dispersion in the environment (Pesce et al. 2009). Stabilisation of pesticides in the buffer zone could be improved by several means such as soil amendment with different compounds, e.g. organic matrices such as biochar, improving adsorption properties or phyto-stabilisation. Furthermore, pesticide biodegradation could be improved by promoting the development of the soil microflora through either nutrient supply or by inoculating microbes (Cheyns et al. 2012), or by the "rhizosphere effect" (Piutti et al. 2002), that is the selection of a plant cover favourable to soil microflora development. A meta-analysis from (Stehle et al. 2011) compared buffer efficiencies obtained from the ARTWET project (Mitigation of agricultural nonpoint-source pesticide pollution and phytoremediation in artificial wetland ecosystems) with previously published results. The authors showed that different kinds of vegetative systems reduce pesticide fluxes, and efficiency depends a great deal on pesticide properties $\left(\mathrm{K}_{\mathrm{OC}}\right)$, leading to a wide range of efficiency rates (from $0 \%$ to $100 \%$ ).

Still pending questions concern the possible transfer of pesticides and their metabolites via sub-surface flow below the buffer zone (Dousset et al. 2010), or the accumulation of bound residues in this zone (Pesce et al. 2009), possibly causing delayed contamination of adjacent water resources. Implementation of buffers is not always easy and acceptance on the part of farmers cannot be taken for granted (Tournebize et al. 2012). All the stakeholders should be committed from the beginning of the mitigation process in order to reach a certain level of efficiency, while accepting compromises.

\section{Monitoring}

\section{Aims and design}

Monitoring has two functions within the RM cycle. First, it is a key element in the evaluation of the effectiveness of measures adopted for reducing risk. The monitoring outcomes 
can be used accordingly in the RM process. Second, monitoring can be used to assess the overall quality of the aquatic compartment. Because the respective expected outcomes are different, monitoring studies dedicated to both purposes may differ in terms of frequency, sample location, (number of) substances etc., and thus be conducted separately. Whatever its goal, monitoring is (or should be) an iterative process that is revised periodically.

Monitoring studies are mostly oriented towards compliance checking. In this perspective, percentiles of measured concentrations are compared with EQSs. In Europe, this has essentially stemmed from the WFD implementation, but the compounds and locations targeted may not be the most relevant for the agricultural sector. The focus is on a limited set of priority substances (EC 2012), with no consideration of effective use for some of them. Conversely, the on-going re-authorisation process in Europe is reducing the number of substances available on the market, and accordingly increasing the amounts of the remaining authorised compounds marketed. On the other hand, introducing new priority substances and developing EQSs is a complex and lengthy process, which is somewhat doomed to be behind the times. More flexible monitoring strategies clearly linked to RM decisions are therefore needed, when it comes to assessing the efficiency of these decisions. Such strategies would be adapted to local RM, including stakeholder involvement in environmental protection policies. In the same perspective, monitoring studies should support the authorisation/re-authorisation process, and show whether the exposure assessments performed within this process are realistic. This process is currently being tested in the Netherlands, following the process described in Fig. 2. Monitoring results are used to prioritise substances, according to EQS exceedance in water bodies. Then registration holders have to analyse the potential causes of exceedance, and submit a plan for reducing emissions. This could lead to authorisation adjustments or other management measures. Interestingly, "plausible" relationships between uses and EQS exceedance, instead of causal relationships, are deemed sufficient. If the EQS exceedance occurred only at the edge of field ditches, the substance would not be on the priority list.

Moreover, there is no harmonised strategy among jurisdictions for sampling site location. Monitoring locations for compliance checking within the WFD context are mostly situated in large rivers and lakes, far downstream of agricultural areas, where there is no longer a strong relation between the aqueous concentrations measured and (changes in) upstream agricultural practices. Besides, a fixed-interval monitoring strategy is mostly adopted to assess the presence of pesticides, neglecting the exposure patterns in the field. This rigid monitoring strategy most likely underestimates the aquatic ecosystems' exposure to pesticides, as the infrequent exposure pattern of these compounds will, to a large extent,

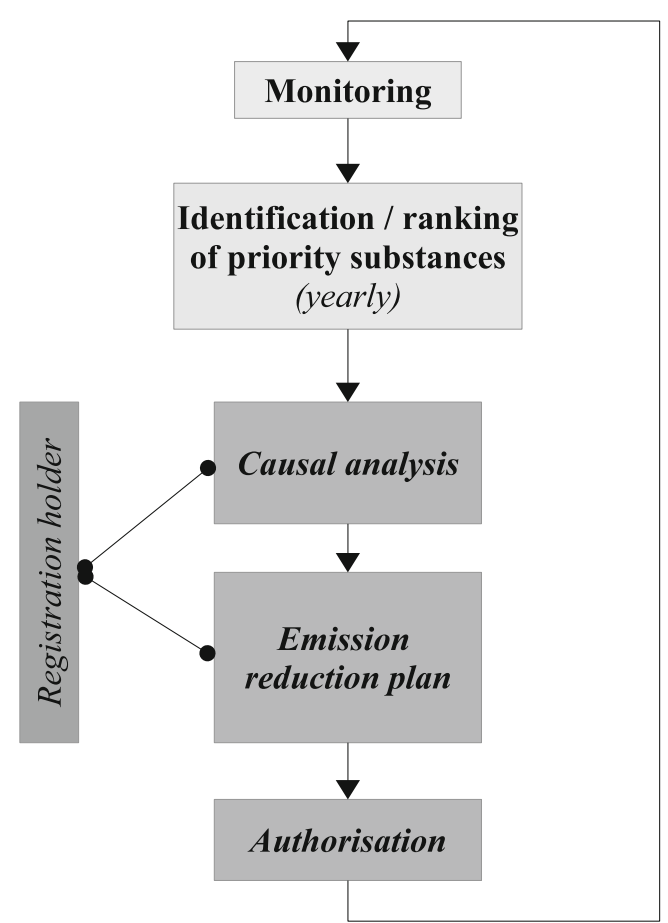

Fig. 2 Proposed flow chart for adaptive management of authorised pesticides based on monitoring results in the Netherlands

remain undetected. Should monitoring provide an extensive spatial coverage of catchments or focus on trends and processes, meaning a more intensive approach in representative catchments? Ideally, a nested design combining two approaches - (1) sampling a large number of catchments with a low temporal resolution and (2) sampling a few representative catchments with a high temporal resolution - would address both goals, but there is currently no example of such a design, and its potential cost remains an unexplored issue. Detailed knowledge of the actual amounts of pesticide applied may not be necessary to identify qualitatively vulnerable water bodies or catchments. The availability of actual pesticide application data is nevertheless a prerequisite for quantitatively estimating the transferred amounts. We therefore argue that these data, which have to be documented by every farmer in the EU for cross-compliance, should be made available in an anonymous and aggregated form to researchers and risk assessors.

Fate models could help to either design efficient (costeffective) monitoring studies, i.e. help to design a sampling strategy adapted to the monitoring objectives, by identifying the mobile compounds, the probable transfer periods, or provide estimates of peak or mean expected concentrations. However, current predicted environmental concentrations (PECs) or pesticide exposure indicators based on modelling (FOCUS 2001) are often difficult to compare to monitoring data (Gauroy \& Carluer 2011). The reasons for this statement are many, including different spatial scales and types of water body or sampling site location, different temporal scales, scale 
extrapolation by modelling and monitoring design leading to missing peak concentrations.

\section{Passive samplers}

Especially when monitoring pesticides, passive samplers have an advantage compared to grab sampling, as they generate a time-integrated picture of the substances which entered the aquatic compartment during the sampling duration. Although peak concentrations will not be detected as such, the time-integrative nature of the technique will significantly reduce the possibility of missing trends in the presence of fluctuating concentrations or episodic peaks of concentrations (Allan et al. 2006; Vrana et al. 2010). Moreover, passive samplers provide lower limits of quantification because they sample higher volumes of water than grab sampling (Allan et al. 2006; Mills et al. 2011). An array of passive samplers is available. Although questions remain on validation, reproducibility and repeatability, it is time to use them more routinely. In particular, partition-based passive samplers such as semipermeable membrane devices (SPMDs) and silicon rubber have been shown to generate reliable results, mostly for hydrophobic compounds (Huckins et al. 1999). With the use of performance reference compounds (PRCs), concentrations on the sampler can be translated to aqueous concentrations (Huckins et al. 2002; Vrana et al. 2010). As for adsorption samplers such as the Polar Organic Chemical Integrative Sampler (POCIS; Alvarez et al. 2004), further developments are needed to correct for exposure conditions (Mazzella et al. 2010; Harman et al. 2011). Currently, POCIS can only be used to estimate the order of magnitude of water concentrations (Harman et al. 2011). A guidance specifying when and how the various samplers could be used is currently needed. If passive samplers were to be used for compliance-checking purposes in the context of the WFD, an additional issue would have to be addressed, namely the establishment of relationships between the dissolved concentrations measured with the samplers and the EQSs, which are expressed as a "total" concentration (i.e. dissolved + adsorbed on suspended particles). This could be performed by considering dissolved organic carbon to water $\left(\mathrm{K}_{\mathrm{DOC}}\right)$ and organic carbon to water ( $\mathrm{K}_{\mathrm{OC}}$ ) partition coefficients (Allan et al. 2009) or by adjusting EQSs to dissolved concentrations, which seems possible since the underlying data are mostly based on laboratory tests, and less frequently mesocosm studies.

\section{Conclusions and recommendations}

Climate change will affect pesticide RA and RM in many ways. There is accordingly an urgent need for more realistic pesticide fate and effect assessment.
- This more realistic fate and effect assessment should account for varying exposure and multiple stresses at the level of ecosystems (i.e. communities for the biological component of ecosystems).

- Consideration of multiple stress and interactions among stressors is even more important in the context of climate change; therefore, the effect assessment step should account for these factors, using probabilities of co-occurrence. The results of this analysis should be included in authorisation rules.

- Combined with ecological modelling, the effects assessed under experimental conditions could be extrapolated to higher spatial and temporal scales.

- Standard RA procedures should account for an appropriate range of important groups of organisms, some of them (e.g. soil microorganisms) still underrepresented in the RA procedure in Europe.

- The overall relevance of RA as well as its realism could benefit from a better understanding of the links between biodiversity and ecosystem services (see (Landis et al. 2013)), and how these services are likely to be affected by climate change. Nevertheless, the preservation of biodiversity should remain as an overarching objective, whatever the link to ecosystem services targeting human welfare.

- In this perspective, more consideration should also be given to time in the higher-tier effect assessment, so that organism recovery, differential effects on different biological traits as well as pesticide fate in the long term can be addressed.

- A better understanding of how climate change is likely to impact the fate of compounds (transport, degradation and persistence) is becoming urgent.

- These considerations might lead to an adaptation of existing tiers of the current RA framework, either by introducing a specific tier or preferably by introducing considerations of climate change impacts at higher tiers.

RM of pesticides must be adapted to climate change: this should lead to the development of adaptive management strategies.

- Land use (crop distribution) and occurrence of pests/ weeds/diseases will evolve accordingly, leading to changes in application patterns, application periods, applied quantities, location and extension of treated areas. Whereas these changes cannot be all anticipated at the authorisation step, post-authorisation monitoring is necessary. Based on current monitoring programs (e.g. in the context of WFD implementation), this process could lead to adjusted use rules (doses, application techniques etc.).

- Besides regulatory monitoring, which occurs at a relatively large scale and targets average contamination, pesticide RM would benefit from focussed monitoring 
studies fitted to the application patterns and compounds' characteristics or to management measures.

- The efficiency of management measures close to the field such as buffer strips or constructed wetlands has to be assessed over the long term (fate of substances and bound residues) as does their sensitivity to varying climatic conditions.

- Fate models and risk indicators should be coupled to predict the efficiency of management measures at several scales, from the plot to the watershed scale. A framework for optimizing the selection of appropriate indicators, harmonising their use and evaluating how climate change would affect their responses (baseline, range of values and class boundaries) should be designed and adopted.

Acknowledgments The authors thank Euraqua and PEER for their support in the organisation of the workshop, as well as Irstea (Scientific and International Affairs Offices) for financial support. We also thank Linda Northrup (English Solutions) for editing the manuscript.

Open Access This article is distributed under the terms of the Creative Commons Attribution License which permits any use, distribution, and reproduction in any medium, provided the original author(s) and the source are credited.

\section{References}

Adriaanse P, Allen R, Gouy V, Hollis J, Hosang J, Jarvis N, Jarvis T, Klein M, Layton R, Linders J, Schäfer H, Smeets L, Yon D (1996) Surface water models and EU registration of plant protection products. European Commission, Brussels

Allan IJ, Vrana B, Greenwood R, Mills GA, Knutsson J, Holmberg A, Guigues N, Fouillac AM, Laschi S (2006) Strategic monitoring for the European Water Framework Directive. TrAC - Trends Anal Chem 25(7):704-715

Allan IJ, Booij K, Paschke A, Vrana B, Mills GA, Greenwood R (2009) Field performance of seven passive sampling devices for monitoring of hydrophobic substances. Environ Sci Technol 43(14):5383-5390

Alvarez DA, Petty JD, Huckins JN, Jones-Lepp TL, Getting DT, Goddard JP, Manahan SE (2004) Development of a passive, in situ, integrative sampler for hydrophilic organic contaminants in aquatic environments. Environ Toxicol Chem 23(7):1640-1648

Arnold JG, Williams JR, Griggs RH, Sammons NB (1991) SWRRBWQ, a basin scale model for assessing management impacts on water quality. USDA Agricultural Research Service, Soil and Water Research Laboratory, Temple

Arts GH, Buijse-Bogdan LL, Belgers JD, van Rhenen-Kersten CH, van Wijngaarden RP, Roessink I, Maund SJ, van den Brink PJ, Brockt TC (2006) Ecological impact in ditch mesocosms of simulated spray drift from a crop protection program for potatoes. Integr Environ Assess Manage 2(2):105-125

Auber A, Roucaute M, Togola A, Caquet T (2011) Structural and functional effects of conventional and low pesticide input cropprotection programs on benthic macroinvertebrate communities in outdoor pond mesocosms. Ecotoxicology 20(8):2042-2055

Barra Caracciolo A, Fajardo C, Grenni P, Saccà ML, Amalfitano S, Ciccoli R, Martin M, Gibello A (2010a) The role of a groundwater bacterial community in the degradation of the herbicide terbuthylazine. FEMS Microbiol Ecol 71(1):127-136
Barra Caracciolo A, Grenni P, Saccà ML (2010b) Effect of the antiviral drug Oseltamivir (Tamiflu) on the bacterial community structure of a surface water ecosystem analyzed using fluorescence in situ hybridization. Bull Environ Contam Toxicol 85(5):443-446

Barra Caracciolo A, Grenni P, Falconi F, Caputo MC, Ancona V, Uricchio VF (2011) Pharmaceutical waste disposal: assessment of its effects on bacterial communities in soil and groundwater. Chem Ecol 27(Suppl 1):43-51

Barra Caracciolo A, Bottoni P, Grenni P (2013) Microcosm studies to evaluate microbial potential to degrade pollutants in soil and water ecosystems. Microchem J 107:126-130

Beketov MA, Foit K, Schäfer RB, Schriever CA, Sacchi A, Capri E, Biggs J, Wells C, Liess M (2009) SPEAR indicates pesticide effects in streams - comparative use of species- and family-level biomonitoring data. Environ Pollut 157(6):1841-1848

Belden JB, Gilliom RJ, Lydy MJ (2007) How well can we predict the toxicity of pesticide mixtures to aquatic life? Integr Environ Assess Manag 3(3):364-372

Bergez JE, Colbach N, Crespo O, Garcia F, Jeuffroy MH, Justes E, Loyce C, Munier-Jolain N, Sadok W (2010) Designing crop management systems by simulation. Eur J Agron 32(1):3-9

Blanck H (2002) A critical review of procedures and approaches used for assessing pollution-induced community tolerance (PICT) in biotic communities. Hum Ecol Risk Assess 8(5):1003-1034. doi:10.1080/1080-700291905792

Bloomfield JP, Williams RJ, Gooddy DC, Cape JN, Guha P (2006) Impacts of climate change on the fate and behaviour of pesticides in surface and groundwater - a UK perspective. Sci Total Environ 369(1-3):163-177

Boesten JJTI, Köpp H, Adriaanse PI, Brock TCM, Forbes VE (2007) Conceptual model for improving the link between exposure and effects in the aquatic risk assessment of pesticides. Ecotoxicol Environ Saf 66(3):291-308

Bouseba B, Zertal A, Beguet J, Rouard N, Devers M, Martin C, MartinLaurent $\mathrm{F}$ (2009) Evidence for 2,4-D mineralisation in Mediterranean soils: impact of moisture content and temperature. Pest Manag Sci 65(9):1021-1029

Brock TC, Arts GH, Maltby L, Van den Brink PJ (2006) Aquatic risks of pesticides, ecological protection goals, and common aims in European Union Legislation. Integr Environ Assess Manag 2(4):e20-e46

Brock TCM, Alix A, Brown CD, Capri E, Gottesbüren BFF, Heimbach F, Lythgo CM, Schulz R, Streloke EE (2010) Linking aquatic exposure and effects: risk assessment of pesticides. SETAC Press \& CRC Press, Taylor \& Francis Group, Boca Raton, London, New York, p. 410

Brock TCM, Arts GHP, ten Hulscher TEM, de Jong FMW, Luttik R, Roex E, Smit CE, van Vliet PJM (2011) Aquatic effect assessment for plant protection products. Wageningen, Alterra

Brown CD (2011) Modelling the fate of pesticides in vegetated filter strips using VFSMOD-W. In: XIV Symposium in Pesticide Chemistry, Piacenza, Italy, 29 August-1 September 2011

Burrows LA, Edwards CA (2002) The use of integrated soil microcosms to predict effects of pesticides on soil ecosystems. Eur J Soil Biol 38(3-4):245-249

Carluer N, De Marsily G (2004) Assessment and modelling of the influence of man-made networks on the hydrology of a small watershed: implications for fast flow components, water quality and landscape management. J Hydrol 285(1-4):76-95

Carsel RF, Imhoff JC, Hummel PR, Cheplick JM, Donigian AS (2003) PRZM-3, a model for predicting pesticide and nitrogen fate in the crop root and unsaturated soil zones: users manual for release 3.12. Center for Exposure Assessment Modeling (CEAM), US Environmental Protection Agency, Athens

Castillo MDP, Torstensson L, Stenström J (2008) Biobeds for environmental protection from pesticide use - a review. J Agric Food Chem 56(15):6206-6219 
Cheyns K, Calcoen J, Martin-Laurent F, Smolders E, Springael D (2012) Effects of dissolved organic matter (DOM) at environmentally relevant carbon concentrations on atrazine degradation by Chelatobacter heintzii SalB. Appl Microbiol Biotechnol 95:1333-1341

DeLong EF, Pace NR (2001) Environmental diversity of bacteria and archaea. Syst Biol 50(4):470-478

Demars BOL, Manson JR, Ólafsson JS, Gíslason GM, Gudmundsdóttir R, Woodward G, Yvon-Durocher G, Perkins DM, Reiss J, Pichler DE, Rasmussen JJ, Friberg N (2011) Temperature and the metabolic balance of streams. Freshwat Biol 56:1106-1121

Devillers J, Farret R, Girardin P, Rivière J-L, Soulas G (2005) Indicateurs pour évaluer les risques liés à l'utilisation des pesticides. Tec \& Doc, Lavoisier (in French), Paris, France

Donigian AS, Imhoff JC, Bicknell BR (1983) Predicting water quality resulting from agricultural nonpoint source pollution via simulationHSPF. Agricultural Management and Water Quality. State University Press, Ames

Doppler T, Camenzuli L, Hirzel G, Krauss M, Lück A, Stamm C (2012) Spatial variability of herbicide mobilisation and transport at catchment scale: insights from a field experiment. Hydrol Earth Syst Sci 16(7):1947-1967

Dousset S, Thévenot M, Schrack D, Gouy V, Carluer N (2010) Effect of grass cover on water and pesticide transport through undisturbed soil columns, comparison with field study (Morcille watershed, Beaujolais). Environ Pollut 158(7):2446-2453

Dubus IG, Reichenberger S, Allier D, Azimonti G, Bach M, Barriuso E, Bidoglio G, Blenkinsop S, Boulahya F, Bouraoui F, Burton A, Centofanti T, Cerdan O, Coquet Y, Feisel B, Fialkiewicz W, Fowler H, Galimberti F, Green A, Grizzetti B, Højberg A, Hollis JM, Jarvis NJ, Kajewski I, Kjær J, Krasnicki S, Lewis KA, Lindahl A, Lobnik F, Lolos P, Mardhel V, Moeys J, Mojon-Lumier F, Nolan BT, Rasmussen P, Réal B, Šinkovec M, Stenemo F, Suhadolc M, Surdyk N, Tzilivakis J, Vaudour-Dupuis E, Vavoulidou-Theodorou E, Windhorst D, Wurm M (2009) FOOTPRINT-Functional tools for pesticide risk assessment and management. www.eu-footprint. org. Final report of the EU project FOOTPRINT (SSPI-CT-2005022704)

Easterling WE, Aggarwal PK, Batima P, Brander KM, Erda L, Howden SM, Kirilenko A, Morton J, Soussana J-F, Schmidhuber J, Tubiello FN (2007) Food, fibre and forest products. In: Parry ML, Canziani OF, Palutikof JP, van der Linden PJ, Hanson CE (eds) Climate change 2007: impacts, adaptation and vulnerability. Contribution of Working Group II to the Fourth Assessment Report of the Intergovernmental Panel on Climate Change. Cambridge University Press, Cambridge, pp 273-313

EC (2000) Directive 2000/60/EC of the European Parliament and of the Council of 23 October 2000 establishing a framework for Community action in the field of water policy, Vol. L 327/1. Official Journal of the European Union, Brussels

EC (2009a) Directive 2009/128/EC of the European Parliament and of the Council of 21 October 2009 establishing a framework for Community action to achieve the sustainable use of pesticides (text with EEA relevance), Vol. 2009/128. Official Journal of the European Union, Brussels

EC (2009b) Regulation (EC) No 1107/2009 of the European Parliament and of the Council concerning the placing of plant protection products on the market and repealing Council Directives 79/117/ EEC and 91/414/EEC of 21 October 2009, Vol. 1107/2009

EC (2012) Proposal for a directive of the European Parliament and of the Council amending Directives 2000/60 EC and 2008/105/ $\mathrm{EC}$ as regards priority substances in the field of water policy. COM(2011) 876 final, Vol. 2011/0429 (COD). European Union, Brussels

Edwards CA (2002) Assessing the effects of environmental pollutants on soil organisms, communities, processes and ecosystems. Eur J Soil Biol 38:225-231
EFSA (2010) Scientific opinion on the development of a soil ecoregions concept using distribution data on invertebrates. EFSA Journal, Vol. 8. European Food Safety Authority, Parma

Falloon P, Betts R (2010) Climate impacts on European agriculture and water management in the context of adaptation and mitigation - the importance of an integrated approach. Sci Total Environ 408(23):5667-5687

Feola G, Rahn E, Binder CR (2011) Suitability of pesticide risk indicators for less developed countries: a comparison. Agric Ecosyst Environ 142(3-4):238-245

Ferrando MD, Andreu-Moliner E, Almar MM, Cebrian C, Nuñez A (1987) Acute toxicity of organochlorined pesticides to the European eel, Anguilla anguilla: the dependency on exposure time and temperature. Bull Environ Contam Toxicol 39(3):365-369

Fisher G, Shah M, Tubiello FN, van Velhuizen H (2005) Socio-economic and climate change impacts on agriculture: an integrated assessment. Philos Trans R Soc Lond Ser B: Biol Sci 360(1463):2067-2083

FOCUS (2001) FOCUS surface water scenarios in the EU evaluation process under 91/414/EEC. Report of the FOCUS Working Group on Surface Water Scenarios. EC document. European Union, Brussels

Freitas LG, Singer H, Müller SR, Schwarzenbach RP, Stamm C (2008) Source area effects on herbicide losses to surface waters - a case study in the Swiss Plateau. Agric Ecosyst Environ 128(3):177-184

Frey MP, Schneider MK, Dietzel A, Reichert P, Stamm C (2009) Predicting critical source areas for diffuse herbicide losses to surface waters: role of connectivity and boundary conditions. J Hydrol 365(1-2):23-36

Friberg N, Dybkjaer JB, Olafsson JS, Gislason GM, Larsen SE, Lauridsen TL (2009) Relationships between structure and function in streams contrasting in temperature. Freshwat Biol 54(10):20512068

Friberg N, Bergfur J, Rasmussen JR, Sandin L (2013) Changing Northern catchments: is altered hydrology, temperature or both going to shape future stream communities and ecosystem processes? Hydrol Process 27:734-740

Galic N, Hommen U, Baveco JM, Van Den Brink PJ (2010) Potential application of population models in the European ecological risk assessment of chemicals II: review of models and their potential to address environmental protection aims. Integr Environ Assess Manag 6(3):338-360

Gascuel-Odoux C, Aurousseau P, Cordier MO, Durand P, Garcia F, Masson V, Salmon-Monviola J, Tortrat F, Trepos R (2009) A decision-oriented model to evaluate the effect of land use and agricultural management on herbicide contamination in stream water. Environ Model Softw 24(12):1433-1446

Gauroy C, Carluer N (2011) Interpretation of data on pesticide residues in surface water in France, by grouping data within homogeneous spatial units. Knowl Managt Aquatic Ecosyst 400:Art. 04 (13 pp)

Gregoire C, Elsaesser D, Huguenot D, Lange J, Lebeau T, Merli A, Mose R, Passeport E, Payraudeau S, Schütz T, Schulz R, TapiaPadilla G, Tournebize J, Trevisan M, Wanko A (2009) Mitigation of agricultural nonpoint-source pesticide pollution in artificial wetland ecosystems. Environ Chem Lett 7(3):205-231

Griffon M (2006) Nourrir la planète. Editions Odile Jacob, Paris (in French)

Grimm V, Ashauer R, Forbes V, Hommen U, Preuss TG, Schmidt A, van den Brink PJ, Wogram J, Thorbek P (2009) CREAM: a European project on mechanistic effect models for ecological risk assessment of chemicals. Environ Sci Pollut Res 16(6):614-617

Harman C, Allan IJ, Bäuerlein PS (2011) The challenge of exposure correction for polar passive samplers - the PRC and the POCIS. Environ Sci Technol 45(21):9120-9121

Hommen U, Baveco JM, Galic N, van den Brink PJ (2010) Potential application of ecological models in the European environmental risk assessment of chemicals. I: Review of protection goals in EU 
directives and regulations. Integr Environ Assess Manag 6(3):325337

Howden SM, Soussana J-F, Tubiello FN, Chhetri N, Dunlop M, Meinke H (2007) Adapting agriculture to climate change. Proc Natl Acad Sci USA 104(50):19691-19696

Huckins JN, Petty JD, Orazio CE, Lebo JA, Clark RC, Gibson VL, Gala WR, Echols KR (1999) Determination of uptake kinetics (sampling rates) by lipid-containing semipermeable membrane devices (SPMDs) for polycyclic aromatic hydrocarbons (PAHs) in water. Environ Sci Technol 33(21):3918-3923

Huckins JN, Petty JD, Lebo JA, Almeida FV, Booij K, Alvarez DA, Cranor WL, Clark RC, Mogensen BB (2002) Development of the permeability/performance reference compound approach for in situ calibration of semipermeable membrane devices. Environ Sci Technol 36(1):85-91

Jacob D, Bärring L, Christensen OB, Christensen JH, De Castro M, Déqué M, Giorgi F, Hagemann S, Hirschi M, Jones R, Kjellström E, Lenderink G, Rockel B, Sánchez E, Schär C, Seneviratne SI, Somot S, Van Ulden A, Van Den Hurk B (2007) An intercomparison of regional climate models for Europe: model performance in present-day climate. Clim Change 81(Suppl 1):31-52

Jeffery S, Gardi C, Jones A, Montanarella L, Marmo L, Miko L, Ritz K, Peres G, Römbke J, Van der Putten WH (2010) European atlas of soil biodiversity. European Commission, Joint Research Center, Ispra. doi: $10.2788 / 94222$

Jeppesen E, Moss B, Bennion H, Carvalho L, DeMeester L, Friberg N, Gessner MO, Lauridsen TL, May L, Meerhoff M, Olafsson JS, Soons MB, Verhoeven JTA (2010) Interaction of climate change and eutrophication. In: Kernan M, Moss B, Battarbee RW (eds) Climate change impacts on freshwater ecosystems - direct effects and interactions with other stresses. Blackwell Science Ltd., Oxford, pp 119-152

Kattwinkel M, Jan-Valentin K, Foit K, Liess M (2011) Climate change, agricultural insecticide exposure, and risk for freshwater communities. Ecol Appl 21(6):2068-2081

Kefford BJ, Liess M, Warne MSJ, Metzeling L, Schäfer RB (2012) Risk assessment of episodic exposures to chemicals should consider both the physiological and the ecological sensitivities of species. Sci Total Environ 441:213-219

Knauert S, Escher B, Singer H, Hollender J, Knauer K (2008) Mixture toxicity of three photosystem II inhibitors (atrazine, isoproturon, and diuron) toward photosynthesis of freshwater phytoplankton studied in outdoor mesocosms. Environ Sci Technol 42(17):64246430

Knauert S, Dawo U, Hollender J, Hommen U, Knauer K (2009) Effects of photosystem II inhibitors and their mixture on freshwater phytoplankton succession in outdoor mesocosms. Environ Toxicol Chem 28(4):836-845

Lagadic L (2011) Utilisation de modèles d'exposition aux pesticides pour la reconstitution et la mise en œuvre de scénarios réalistes de contamination de mésocosmes permettant d'étudier les impacts d'itinéraires techniques sur les organismes aquatiques-EMERITAT (Rapport final, contrat 000077). Ministère de l'Ecologie et du Développement Durable, Paris (in French)

Landis WG, Durda JL, Brooks ML, Chapman PM, Menzie CA, Stahl RG, Stauber JL (2013) Ecological risk assessment in the context of global climate change. Environ Toxicol Chem 32(1):79-92

Larsbo M, Roulier S, Stenemo F, Kasteel R, Jarvis N (2005) An improved dual-permeability model of water flow and solute transport in the vadose zone. Vadose Zone J 4(2):398-406

Ledger ME, Brown LE, Edwards FK, Milner AM, Woodward G (2013) Drought alters the structure and functioning of complex food webs. Nat Clim Chang 3:223-227

Lehmann N, Finger R, Klein T, Calanca P, Walter A (2013) Adapting crop management practices to climate change: modeling optimal solutions at the field scale. Agric Syst 117:55-65
Lehner B, Döll P, Alcamo J, Henrichs T, Kaspar F (2006) Estimating the impact of global change on flood and drought risks in Europe: a continental, integrated analysis. Clim Chang 75(3):273-299

Leu C, Singer H, Stamm C, Müller SR, Schwarzenbach RP (2004) Variability of herbicide losses from 13 fields to surface water within a small catchment after a controlled herbicide application. Environ Sci Technol 38(14):3835-3841

Levinsky I, Skov F, Svenning J-C, Rahbek C (2007) Potential impacts of climate change on the distributions and diversity patterns of European mammals. Biodivers Conserv 16(13):3803-3816. doi:10. 1007/s10531-007-9181-7

Liess M, Beketov M (2011) Traits and stress: keys to identify community effects of low levels of toxicants in test systems. Ecotoxicology 20(6):1328-1340

Liscio C, Magi E, Di Carro M, Suter MJF, Vermeirssen ELM (2009) Combining passive samplers and biomonitors to evaluate endocrine disrupting compounds in a wastewater treatment plant by LC/MS/ MS and bioassay analyses. Environ Pollut 157(10):2716-2721

Lydy MJ, Belden JB, Ternes MA (1999) Effects of temperature on the toxicity of M-parathion, chlorpyrifos, and pentachlorobenzene to Chironomus tentans. Arch Environ Contam Toxicol 37(4):542547

Mazzella N, Lissalde S, Moreira S, Delmas F, Mazellier P, Huckins JN (2010) Evaluation of the use of performance reference compounds in an oasis-HLB adsorbent based passive sampler for improving water concentration estimates of polar herbicides in freshwater. Environ Sci Technol 44(5):1713-1719

Meerhoff M, Clemente JM, Teixeira De Mello F, Iglesias C, Pedersen AR, Jeppesen E (2007) Can warm climate-related structure of littoral predator assemblies weaken the clear water state in shallow lakes? Glob Chang Biol 13(9):1888-1897

Mills GA, Greenwood R, Vrana B, Allan IJ, Ocelka T (2011) Measurement of environmental pollutants using passive sampling devices - a commentary on the current state of the art. J Environ Monit 13(11):2979-2982

Milosevic N, Thomsen NI, Juhler RK, Albrechtsen HJ, Bjerg PL (2012) Identification of discharge zones and quantification of contaminant mass discharges into a local stream from a landfill in a heterogeneous geologic setting. J Hydrol 446-447:13-23

Mocali S, Benedetti A (2010) Exploring research frontiers in microbiology: the challenge of metagenomics in soil microbiology. Res Microbiol 161(6):497-505

Moe SJ, De Schamphelaere K, Clements WH, Sorensen MT, Van den Brink PJ, Liess M (2013) Combined and interactive effects of global climate change and toxicants on populations and communities. Environ Toxicol Chem 32(1):49-61

Morin S, Pesce S, Kim-Tiam S, Libert X, Coquery M, Mazzella N (2012) Use of polar organic chemical integrative samplers to assess the effects of chronic pesticide exposure on biofilms. Ecotoxicology 21(5):1570-1580

Moussa R, Chahinian N, Bocquillon C (2007) Distributed hydrological modelling of a Mediterranean mountainous catchment - model construction and multi-site validation. J Hydrol 337(1-2):35-51

Muller R, Tang JYM, Thier R, Mueller JF (2007) Combining passive sampling and toxicity testing for evaluation of mixtures of polar organic chemicals in sewage treatment plant effluent. J Environ Monit 9(1):105-110

Muñoz-Carpena R, Parsons JE (2011) VFSMOD-W vegetative filter strips modelling system. Model documentation \& user's manual. Version 6.x. http://abe.ufl.edu/carpena/files/pdf/software/vfsmod/ VFSMOD_UsersManual_v6.pdf

Neitsch SL, Arnold JG, Kiniry JR, Williams JR (2009) Soil and water assessment tool. Theoretical documentation, Version 2009. http:// twri.tamu.edu/reports/2011/tr406.pdf

Netten JC, Arts GH, Gylstra R, van Nes EH, Scheffer M, Roijackers RMM (2010) Effect of temperature and nutrients on the 
competition between free-floating Salvinia natans and submerged Elodea nuttallii in mesocosms. Fundam Appl Limnol 177(2):125132

Nienstedt KM, Brock TCM, van Wensem J, Montforts M, Hart A, Aagaard A, Alix A, Boesten J, Bopp SK, Brown C, Capri E, Forbes V, Köpp H, Liess M, Luttik R, Maltby L, Sousa JP, Streissl F, Hardy AR (2012) Development of a framework based on an ecosystem services approach for deriving specific protection goals for environmental risk assessment of pesticides. Sci Total Environ 415:31-38

Olesen JE, Bindi M (2002) Consequences of climate change for European agricultural productivity, and land use and policy. Eur J Agron 16(4):239-262

Parmesan C, Yohe G (2003) A globally coherent fingerprint of climate change impacts across natural systems. Nature 421(6918):37-42

Perkins DM, Yvon-Durocher G, Demars BOL, Reiss J, Pichler DE, Friberg N, Trimmer M, Woodward G (2012) Consistent temperature dependence of respiration across ecosystems contrasting in thermal history. Glob Chang Biol 18(4):1300-1311

Pesce S, Martin-Laurent F, Rouard N, Montuelle B (2009) Potential for microbial diuron mineralisation in a small wine-growing watershed: from treated plots to lotic receiver hydrosystem. Pest Manag Sci 65(6):651-657

Pesce S, Morin S, Lissalde S, Montuelle B, Mazzella N (2011) Combining polar organic chemical integrative samplers (POCIS) with toxicity testing to evaluate pesticide mixture effects on natural phototrophic biofilms. Environ Pollut 159(3):735-741

Pesce S, Bouchez A, Montuelle B (2012) Effects of organic herbicides on phototrophic microbial communities in freshwater ecosystems. Rev Environ Contam Toxicol 214:87-124

Pinet F, Miralles A, Bimonte S, Vernier F, Carluer N, Gouy V, Bernard S (2010) The use of UML to design agricultural data warehouses. In: AgEng 2010, International Conference on Agricultural Engineering, Clermont-Ferrand, France, 6-8 Sep 2010

Piutti S, Hallet S, Rousseaux S, Philippot L, Soulas G, Martin-Laurent F (2002) Atrazine accelerated mineralisation in maize rhizosphere soil. Biol Fertil Soils 36:434-441

Prato E, Scardicchio C, Biandolino F (2008) Effects of temperature on the acute toxicity of cadmium to Corophium insidiosum. Environ Monit Assess 136(1-3):161-166

Rabiet M, Margoum C, Gouy V, Carluer N, Coquery M (2010) Assessing pesticide concentrations and fluxes in the stream of a small vineyard catchment - effect of sampling frequency. Environ Pollut 158(3):737-748

Rasmussen JJ, McKnight US, Loinaz MC, Thomsen NI, Olsson ME, Bjerg PL, Binning PJ, Kronvang B (2013) A catchment scale evaluation of multiple stressor effects in headwater streams. Sci Total Environ 442:420-431

Reichenberger S, Bach M, Skitschak A, Frede HG (2007) Mitigation strategies to reduce pesticide inputs into groundand surface water and their effectiveness: a review. Sci Total Environ 384(1-3):1-35

Reus J, Leendertse P, Bockstaller C, Fomsgaard I, Gutsche V, Lewis K, Nilsson C, Pussemier L, Trevisan M, van der Werf H, Alfarroba F, Blümel S, Isart J, McGrath D, Seppälä T (2002) Comparison and evaluation of eight pesticide environmental risk indicators developed in Europe and recommendations for future use. Agric Ecosyst Environ 90(2):177-187

Schiedek D, Sundelin B, Readman JW, Macdonald RW (2007) Interactions between climate change and contaminants. Mar Pollut Bull 54(12):1845-1856

Schmitt-Jansen M, Veit U, Dudel G, Altenburger R (2008) An ecological perspective in aquatic ecotoxicology: approaches and challenges. Basic Appl Ecol 9(4):337-345

Schneider M (2008) A general model for the design of data warehouses. Int J Prod Econ 112(1):309-325
Schofield O, Ducklow HW, Martinson DG, Meredith MP, Moline MA, Fraser WR (2010) How do polar marine ecosystems respond to rapid climate change? Science 328(5985):1520-1523

Shaw M, Negri A, Fabricius K, Mueller JF (2009) Predicting water toxicity: pairing passive sampling with bioassays on the Great Barrier Reef. Aquat Toxicol 95(2):108-116

Stahl RG, Hooper MJ, Balbus JM, Clements W, Fritz A, Gouin T, Helm R, Hickey C, Landis W, Moe SJ (2013) The influence of global climate change on the scientific foundations and applications of environmental toxicology and chemistry: introduction to a SETAC international workshop. Environ Toxicol Chem 32(1):13-19

Stehle S, Elsaesser D, Gregoire C, Imfeld G, Niehaus E, Passeport E, Payraudeau S, Schäfer RB, Tournebize J, Schulz R (2011) Pesticide risk mitigation by vegetated treatment systems: a metaanalysis. J Environ Qual 40(4):1068-1080

Supit I, van Diepen CA, De Wit AJW, Wolf J, Kabat P, Baruth B, Ludwig F (2012) Assessing climate change effects on European crop yields using the crop growth monitoring system and a weather generator. Agric For Meteorol 164:96-111

Thomas CD, Cameron A, Green RE, Bakkenes M, Beaumont LJ, Collingham YC, Erasmus BFN, de Siqueira MF, Grainger A, Hannah L, Hughes L, Huntley B, van Jaarsveld AS, Midgley GF, Miles L, Ortega-Huerta MA, Peterson AT, Phillips OL, Williams SE (2004) Extinction risk from climate change. Nature 427(6970):145-148

Tiktak A, van den Berg F, Boesten JJTI, Leistra M, van der Linden AMA, van Kraalingen D (2000) Pesticide emission assessment at regional and local scales: user manual of FOCUS Pearl version 1.1.1. RIVM, Alterra, Bilthoven

Tlili A, Montuelle B (2011) Microbial pollution-induced community tolerance. In: Amiard-Triquet C, Rainbow PS, Roméo M (eds) Tolerance to environmental contaminants. Environmental and ecological risk assessment. CRC, London, pp 85-108

Tournebize J, Gramaglia C, Birmant F, Bouarfa S, Chaumont C, Vincent B (2012) Co-design of constructed wetlands to mitigate pesticide pollution in a drained catch-basin: a solution to improve groundwater quality. Irrig Drain 61(Suppl 1):75-86

Turbé A, De Toni A, Benito P, Lavelle P, Lavelle P, Ruiz N, Van der Putten WH, Labouze E, Mudgal S (2010) Soil biodiversity: functions, threats and tools for policy makers. Bio Intelligence Service, IRD, and NIOO, Report for European Commission (DG Environment), 2010, Brussels. http://ec.europa.eu/environment/soil/ pdf/biodiversity report.pdf

Udikovic-Kolic N, Devers-Lamrani M, Petric I, Hrsak D, MartinLaurent F (2011) Evidence for taxonomic and functional drift of an atrazine-degrading culture in response to high atrazine input. Appl Microbiol Biotechnol 90:1547-1554

USEPA, Guidelines for Ecological Risk Assessment (1998) US environmental protection agency. Washington D.C., USA., p. 159

Van De Meent D, Huijbregts MAJ (2005) Calculating life-cycle assessment effect factors from potentially affected fraction-based ecotoxicological response functions. Environ Toxicol Chem 24(6):1573-1578

Van Den Brink PJ, Baveco JM, Verboom J, Heimbach F (2007) An individual-based approach to model spatial population dynamics of invertebrates in aquatic ecosystems after pesticide contamination. Environ Toxicol Chem 26(10):2226-2236

Van den Brink PJ, Crum SJH, Gylstra R, Bransen F, Cuppen JGM, Brock TCM (2009) Effects of a herbicide-insecticide mixture in freshwater microcosms: risk assessment and ecological effect chain. Environ Pollut 157(1):237-249

van Straalen NM, Feder ME (2012) Ecological and evolutionary functional genomics - how can it contribute to the risk assessment of chemicals? Environ Sci Technol 46(1):3-9. doi:10.1021/es2034153

Vanclooster M, Boesten JJTI, Trevisan M, Brown CD, Capri E, Eklo OM, Gottesbüren B, Gouy V, Van Der Linden AMA (2000) A European test of pesticide-leaching models: methodology and major recommendations. Agric Water Manage 44(1-3):1-19 
Vischetti C, Capri E, Trevisan M, Casucci C, Perucci P (2004) Biomassbed: a biological system to reduce pesticide point contamination at farm level. Chemosphere 55(6):823-828

Vörösmarty CJ, McIntyre PB, Gessner MO, Dudgeon D, Prusevich A, Green P, Glidden S, Bunn SE, Sullivan CA, Liermann CR, Davies PM (2010) Global threats to human water security and river biodiversity. Nature 468(7321):334-334

Vrana B, Vermeirssen EL, Allana IJ, Kohoutek J, Kennedy K, Mills G, Greenwood R (2010) Passive sampling of emerging pollutants in the aquatic environment: state of the art and perspectives. NORMAN position paper. NORMAN Association, Prague
Woodward G, Dybkjaer JB, Olafsson JS, Gislason GM, Hannesdottir ER, Friberg N (2010) Sentinel systems on the razor's edge: effects of warming on Arctic geothermal stream ecosystems. Glo Chang Biol 16(7):1979-1991

Yli-Viikari A, Hietala-Koivu R, Huusela-Veistola E, Hyvönen T, Perälä P, Turtola E (2007) Evaluating agri-environmental indicators (AEIs) - use and limitations of international indicators at national level. Ecol Indic 7(1):150-163

Zhang C, Wu J, Grimm NB, McHale M, Buyantuyev A (2013) A hierarchical patch mosaic ecosystem model for urban landscapes: model development and evaluation. Ecol Model 250:81-100 